\title{
3D MODELING MESIN EPI (ELECTRON POWER INVERTER) PADA PT. JABAR UTAMA ENGINEERING MENGGUNAKAN SOFTWARE BLENDER
}

\author{
Dion Eko Valentino, S.S., M.Kom. \\ Dosen Program Studi Manajemen Informatika \\ Politeknik LP3I Bandung \\ e-mail : dion.plb@gmail.com
}

\begin{abstract}
Abstrak : Perkembangan jaman yang sangat pesat saat ini menuntut semua bidang beralih ke arah media digital. Pada jaman dahulu perusahaan akan mengeluarkan biaya yang besar untuk mendesain sebuah produk hingga menjadi produk jadi, itupun masih menggunakan media 2 dimensi, sehingga menyulitkan untuk melihat dari berbagai sudut pandang. Salah satu contohnya yaitu, bagi sektor atau perusahaan yang akan membuat sebuah produk harus memproduksi sebuah prototype, dimana biaya yang dikeluarkan akan besar, dikarenakan jika pada saat desain tidak sesuai maka akan membuat prototype lainnya. Pengembangan media digital dalam mendesain produk akhir-akhir ini banyak dilakukan oleh perusahaan. Salah satu software yang mendukung desain produk dalam bentuk 3 dimensi adalah Blender. Blender adalah salah satu software gratis atau biasa disebut open source $3 d$ creation suite, yang mendukung seluruh pengerjaan dalam mode 3 dimensi seperti, modeling, rigging, animating, simulation, rendering dan motion tracking. Bahkan software ini juga mendukung dalam pembuatan game.
\end{abstract}

Kata Kunci : 3d modeling, desain, blender

\section{Pendahuluan}

Desain produk pada perusahaan kecil khususnya di negara Indonesia masih di lakukan secara manual dengan menggunakan cara yang konvensional seperti mendesain pada kertas (buku). Dengan kemajuan teknologi yang ada, sudah seharusnya desain produk mengalami pembaharuan dengan memanfaatkan software atau aplikasi pendukung. Sehingga bisa dapat meningkatkan efisiensi di perusahaan-perusahaan tersebut.

Pada saat ini hampir seluruh perusahaan memiliki dan menggunakan komputer. Kemajuan teknologi informasi yang semakin pesat telah mempengaruhi perkembangan software pendukung kerja serta kecanggihan komputer yang semakin pesat pula. Hampir seluruh bidang pekerjaan saat ini menggunakan komputer, mulai dari mengetik, menggambar, menghitung, bahkan trend yang sedang ramai akhir-akhir ini yaitu, jual beli atau promosi produk menggunakan media komputer. Hal ini juga sejalan dengan cara men-desain sebuah produk, yang mana harus dapat mengikuti perkembangan teknologi dengan berpindah dari asalnya hanya menggunakan desain 2 dimensi menjadi 3 dimensi 


\section{Sistem Yang Berjalan}

\subsection{Flowchart Pembuatan Desain Produk}

\section{PT. JABAR UTAMA ENGINEERING}

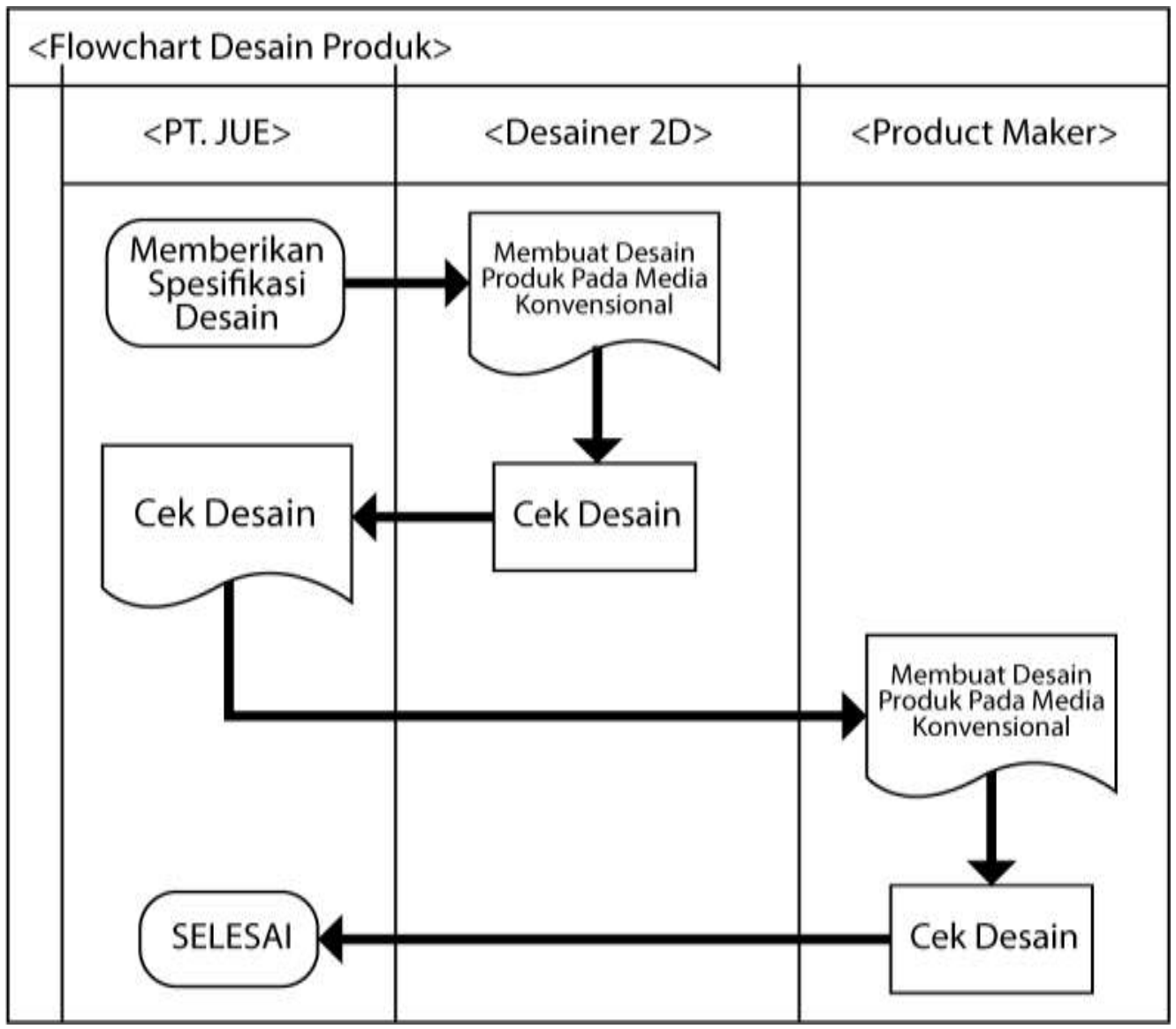

Gambar 1. Flowchart Pembuatan Desain Produk

\section{Kebutuhan Pengguna}

Berdasarkan hasil wawancara, maka penulis melakukan pengamatan langsung pada perusahaan dengan menyediakan pertanyaan kepada yang bersangkutan dan memperoleh kebutuhan pengguna sebagai berikut:

a. Membuat modeling produk secara 3 dimensi.

b. Menggunakan model 3d yang dapat dilihat dari berbagai sudut pandang sehingga mengurangi resiko kesalahan desain pada saat produksi.

c. Menggunakan model 3d yang telah dibuat sebagai bahan promosi.

\section{Ruang Lingkup Produk}

Mengingat permasalah yang ada terlalu luas, maka penulis membatasi masalah sebagai berikut:

a. Model 3d yang dibuat hanya produk mesin EPI (Electron Power Inverter), dengan jenis mesin 3000W. 
b. Software yang digunakan dalam membuat model produk ini hanya menggunakan Blender.

\section{Pembahasan}

PT. Jabar Utama Engineering berdiri pada tahun 2007 bergerak di bidang konstruksi baja, pembuatan komponen alat berat, pembuatan tanki, pemipaan (piping) dan pekerjaan sipil. Dengan berbekal pengalaman di berbagai jenis pekerjaan/proyek serta didukung oleh tenaga-tenaga yang terampil dan berkeahlian. Beberapa produk yang telah dihasilkan atau pun yang sedang dikembangkan yaitu, pembangkit energi seperti contohnya water heater, water pump, solar panel, wind energy panel, EPI dan lainnya.

PT. Jabar Utama Engineering memiliki sebuah workshop seluas $2.500 \mathrm{~m} 2$ dengan sejumlah fasilitas seperti mesin las $\mathrm{CO}$, over head crane 5 ton, bending machine, roll machine dan cutting machine. Workshop yang berlokasi di sekitar kawasan industri Bekasi Jawa Barat, memiliki akses yang mudah untuk transportasi dan mobilisasi.

Beberapa customer yang telah memakai jasa PT. Jabar Utama Engineering yaitu:

a. PT. AT Indonesia

b. PT. Hitachi Construction Machinery Indonesia

c. PT. Katsushiro Machinery Indonesia

d. PT. Komatsu Indonesia

e. PT. Wijaya Karya

f. PT. Astra Honda Motor

g. PT. Patria

h. PT. Alfa Prima Panel

i. PT. Eka Ciptani Pratama

j. PT. Ohgishi Indonesia

k. PT. Lampiri Jaya Abadi

\subsection{Pengguna Produk}

Setelah melakukan penelitian yang berhubungan dengan system desain yang dilakukan oleh PT. Jabar Utama Engineering, dapat diketahui bahwa system desain masih manual atau biasa disebut konvensional, perusahaan tidak bisa melihat hasil desain secar 3 dimensi.

Oleh karena itu penulis membuat desain dengan menggunakan teknik 3 dimensi, dimana desain tersebut dapat mempermudah perusahaan dalam melihat produk yang di desain secara 3 dimensi dan sapat dilihat dari beberapa prespektif tanpa harus memperbanyak desain lagi. Selain itu juga diharapkan dengan adanya desain secar 3 dimensi, perusahaan dapat mengurangi kesalahan dalam pembuatan prototype.

\subsection{Prosedur Sistem Usulan}

Setelah mengetahui gambaran sistem lama maka dapat dilakukan pembaharuan dalam sistem yang berjalan. Dengan usulan sistem yang baru diharapkan perusahaan dapat mengurangi tingkat kerugian dalam cacat produksi dan juga dapat meningkatkan efisiensi waktu dalam produksi prototype produk baru. 


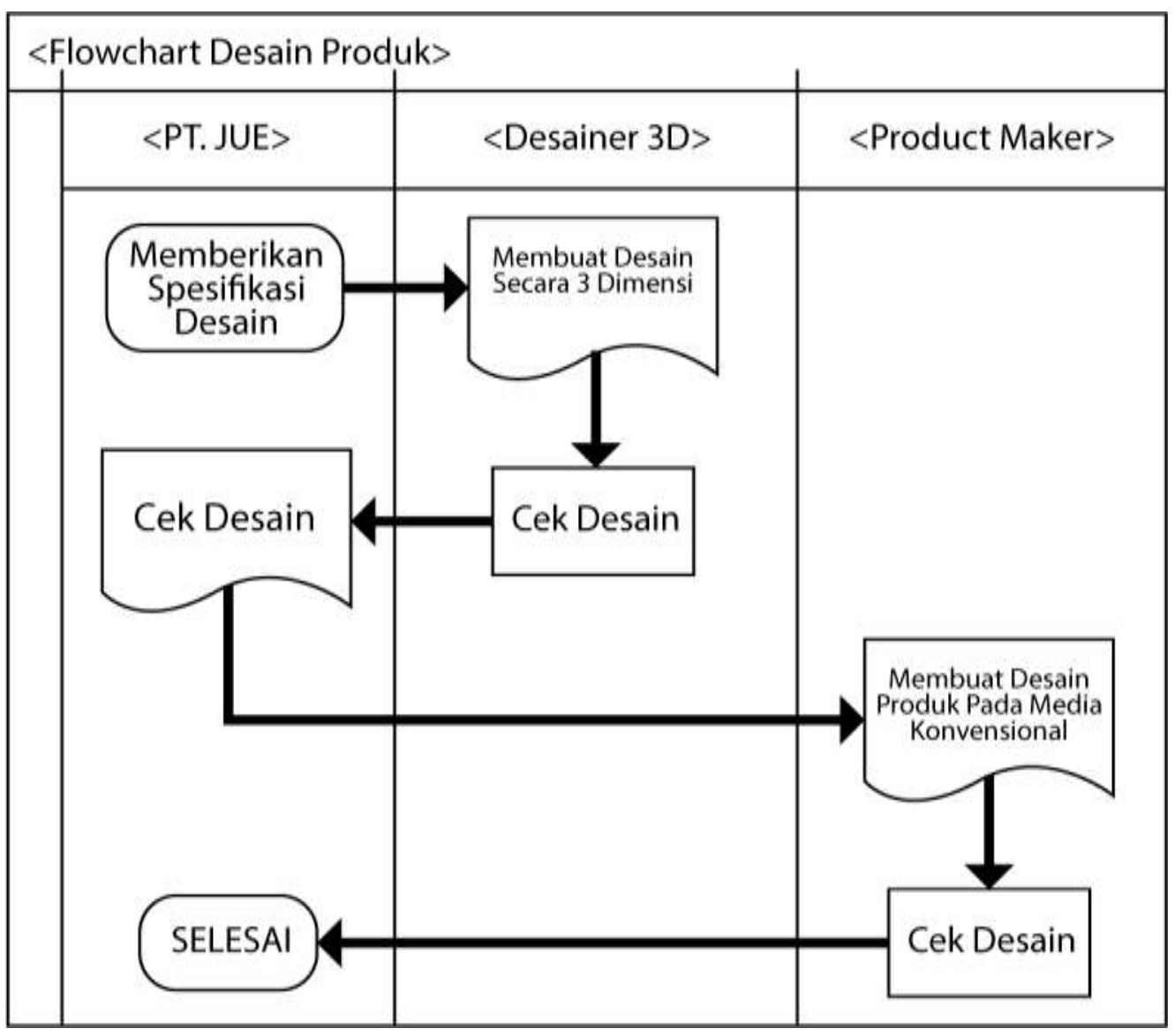

Gambar 2. Flowchart Usulan

Dalam perancangan desain ini, aplikasi yang digunakan penulis dalam pembuatan modeling mesin EPI pada PT. Jabar Utama Engineering yaitu menggunakan aplikasi Blender karena program tersebut mencakup seluruh tools yang diperlukan penulis dalam pembuatan model mesin 3 dimensi EPI. Selain itu, program blender juga merupakan program gratis atau biasa disebut open source software dimana dapat mengurangi biaya produksi, tetapi sangat mumpuni untuk membuat sebuah proyek 3 dimensi.

\subsection{Spesifikasi Sofware dan Hardware}

a. Perangkat lunak (Sofware) yang diunakan pada saat perancangan aplikasi adalah

1) OS Windows 10 64-bit

2) Blender 2.5

3) Adobe Photoshop

4) Adobe Illustrator

5) Microsoft Visio 2013

6) Microsoft Paint 3d

7) Google Chrome

b. Perangkat keras (hardware) yang digunakan pada saat perancangan aplikasi adalah:

1) Intel Pentium Core i7 $2.10 \mathrm{GHz}$ 
2) RAM dengan kapasitas 8.00 GB

3) Harddisk dengan kapasitas 1 Tera

4) Display Mode1600x900

5) Monitor

6) Wifi

7) Keyboard Dan Mouse

\section{Perancangan Model}

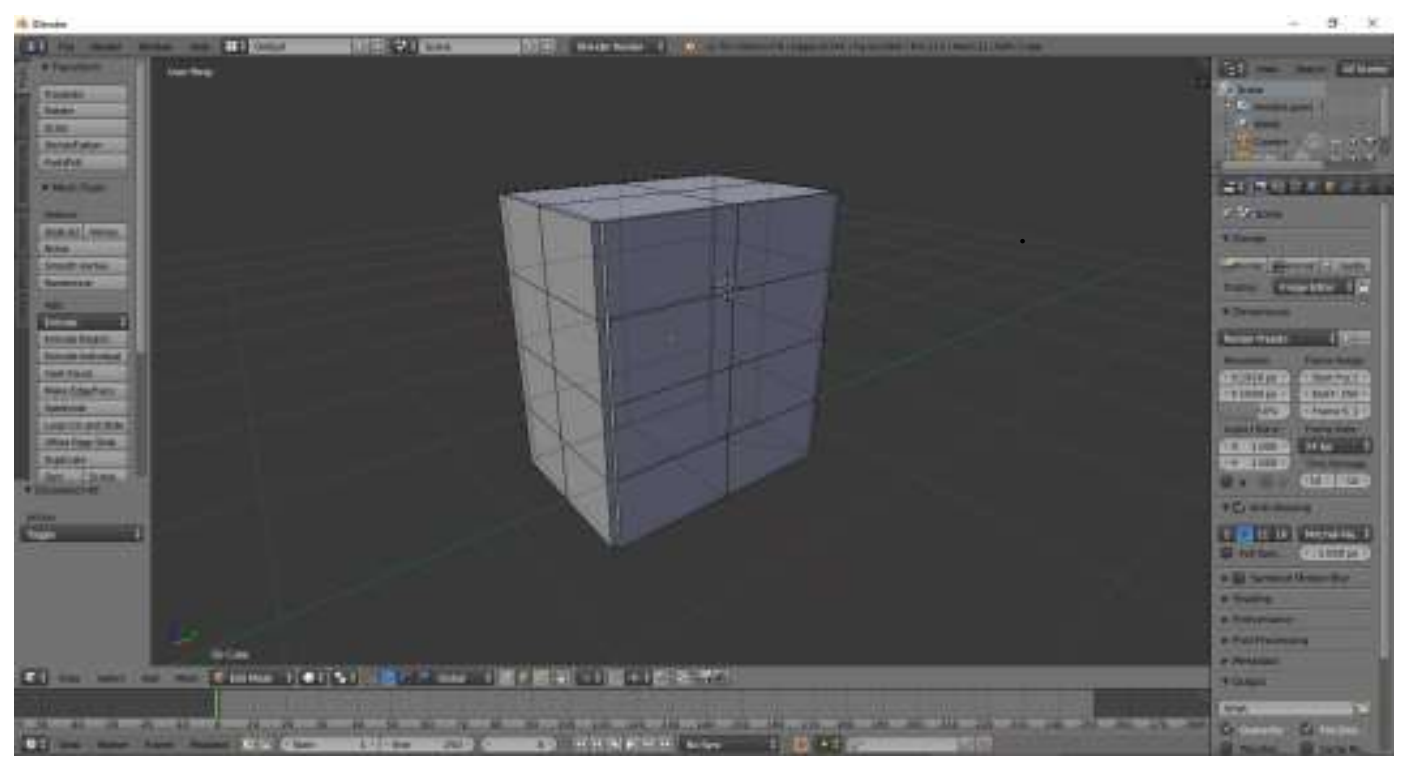

Gambar 3. Perancangan model dengan teknik subdivide objek dan menghilangkan face

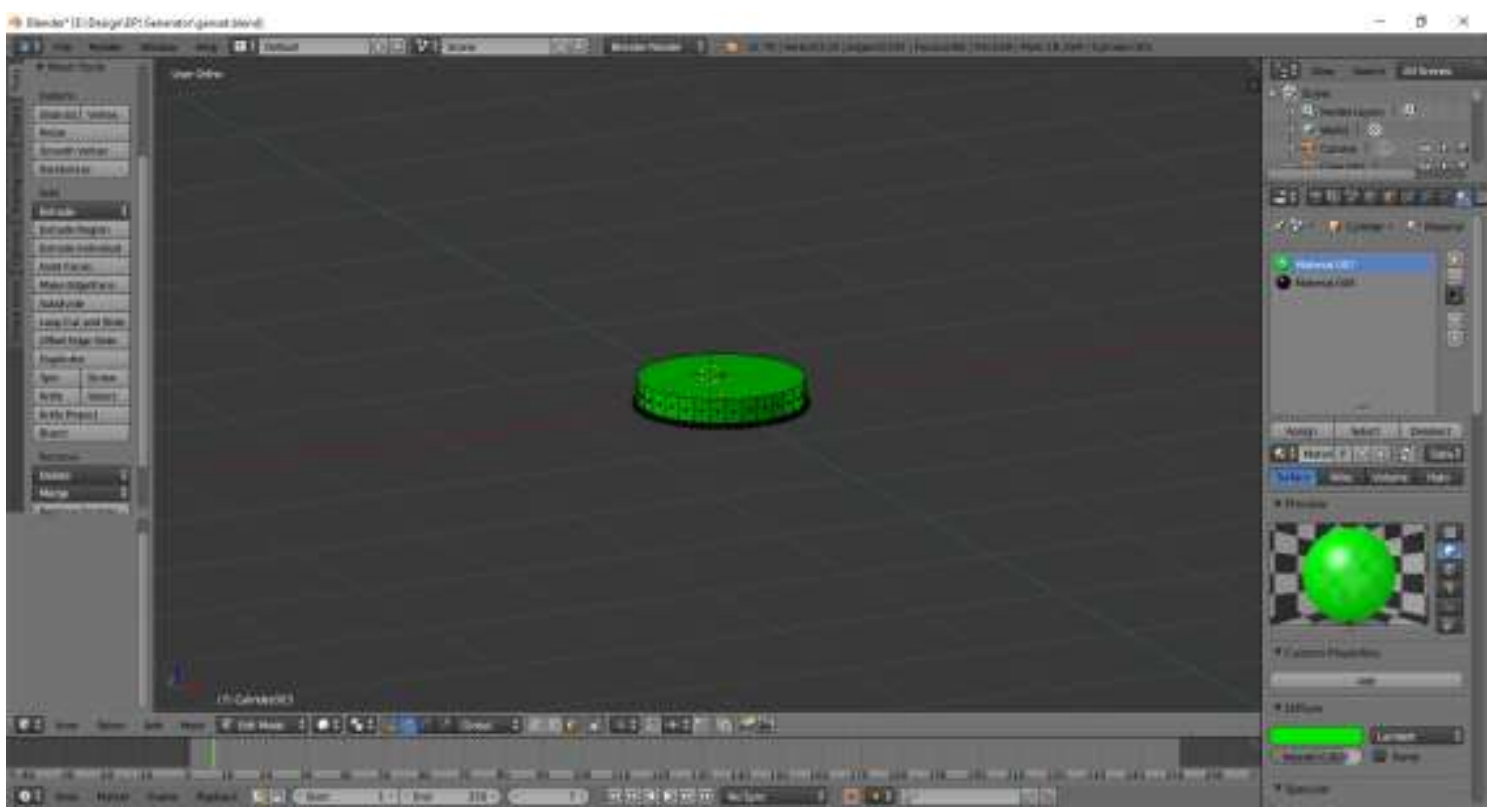

Gambar 4. Perancangan model indicator lamp green dengan teknik subdivide objek dan menghilangkan face serta memberikan warna material dengan teknik glass 


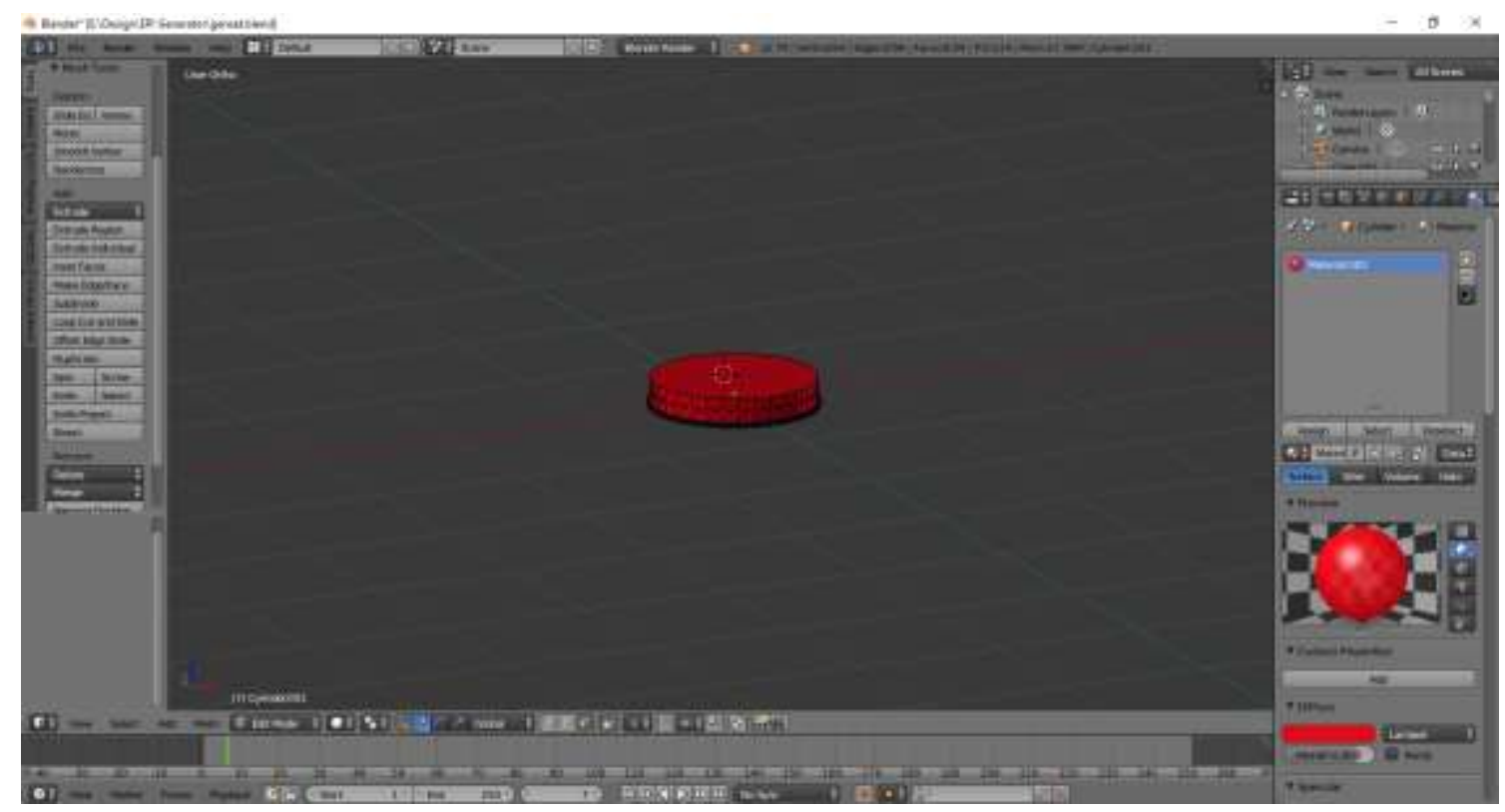

Gambar 5. Perancangan model indicator lamp red dengan teknik subdivide objek dan menghilangkan face serta memberikan warna material dengan teknik glass

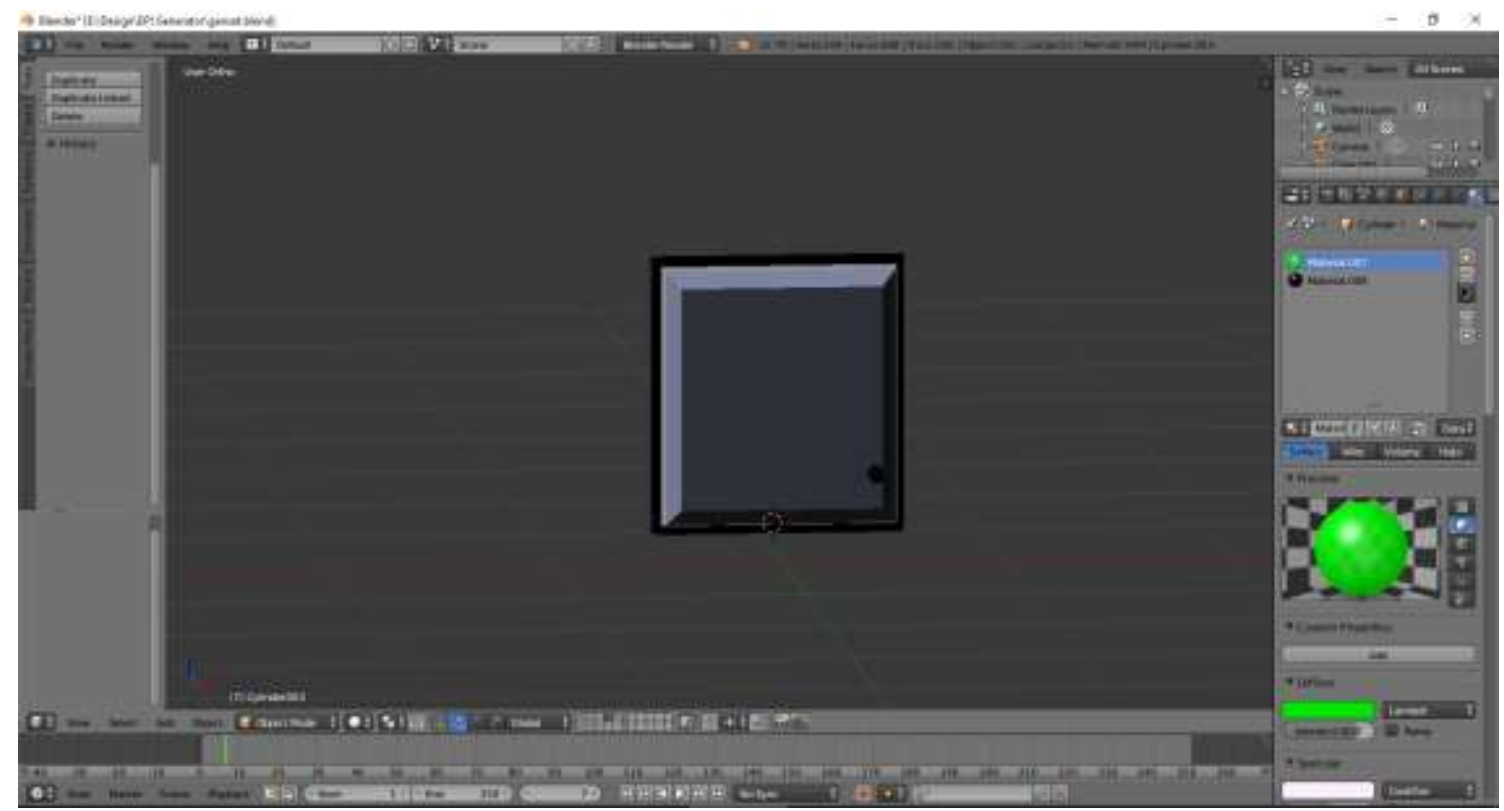

Gambar 6. Perancangan model panel watt indicator dengan teknik subdivide objek dan menghilangkan face serta memberikan warna material dengan teknik glass 


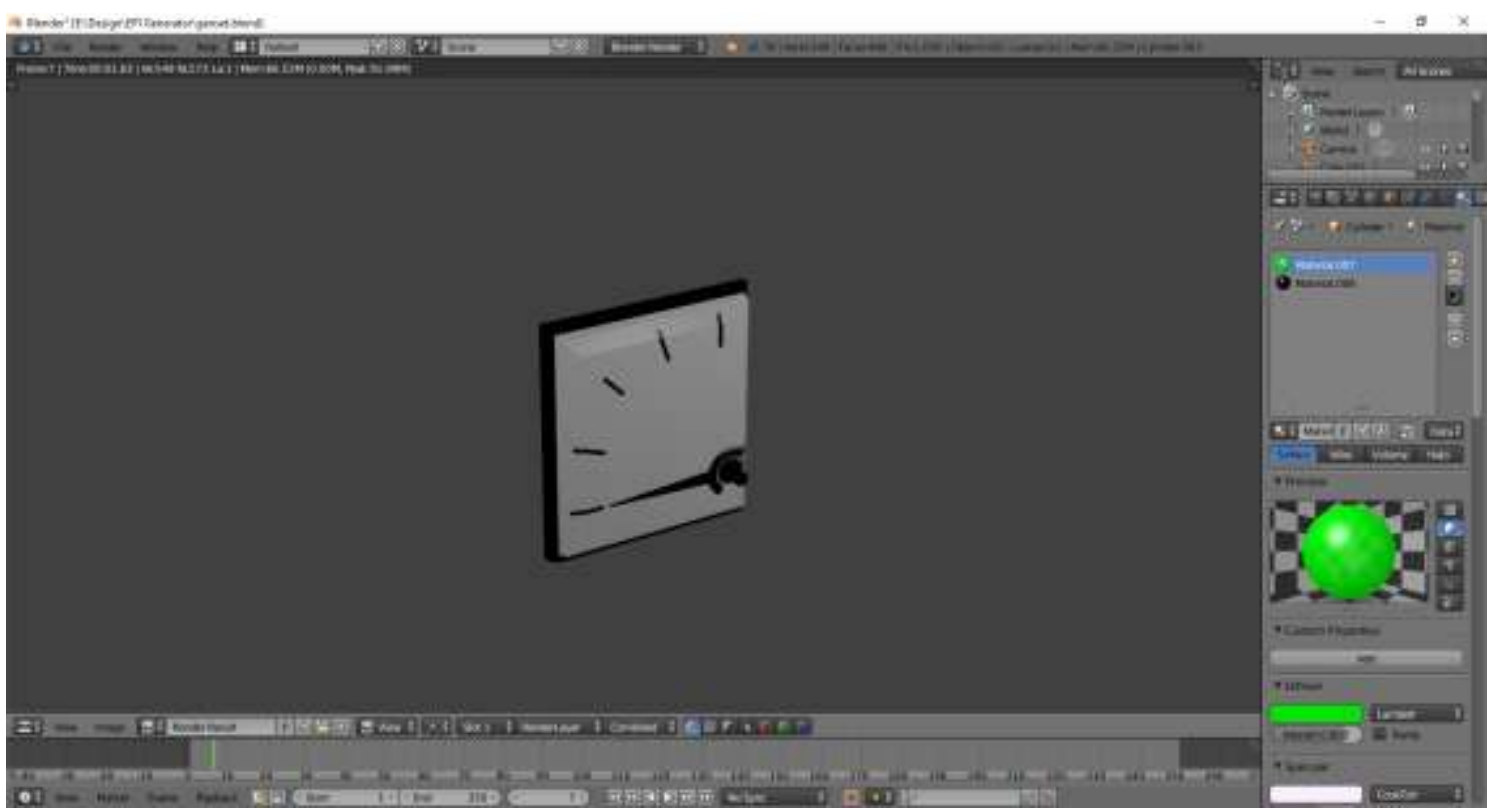

Gambar 7. Hasil rendering panel watt indicator

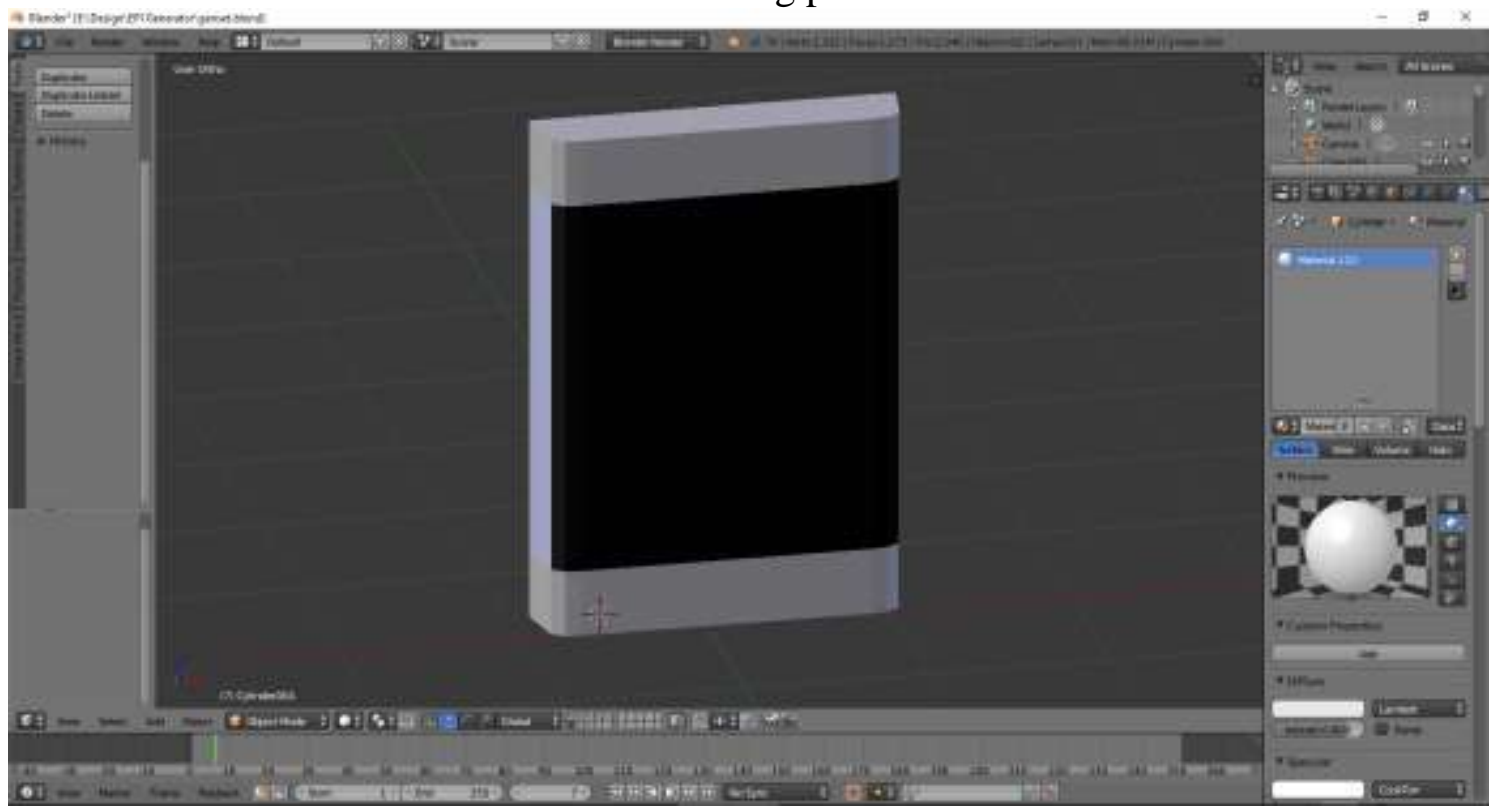

Gambar 8. Perancangan model panel watt indicator switch dengan teknik subdivide objek dan menghilangkan face serta memberikan warna material dengan teknik glass 


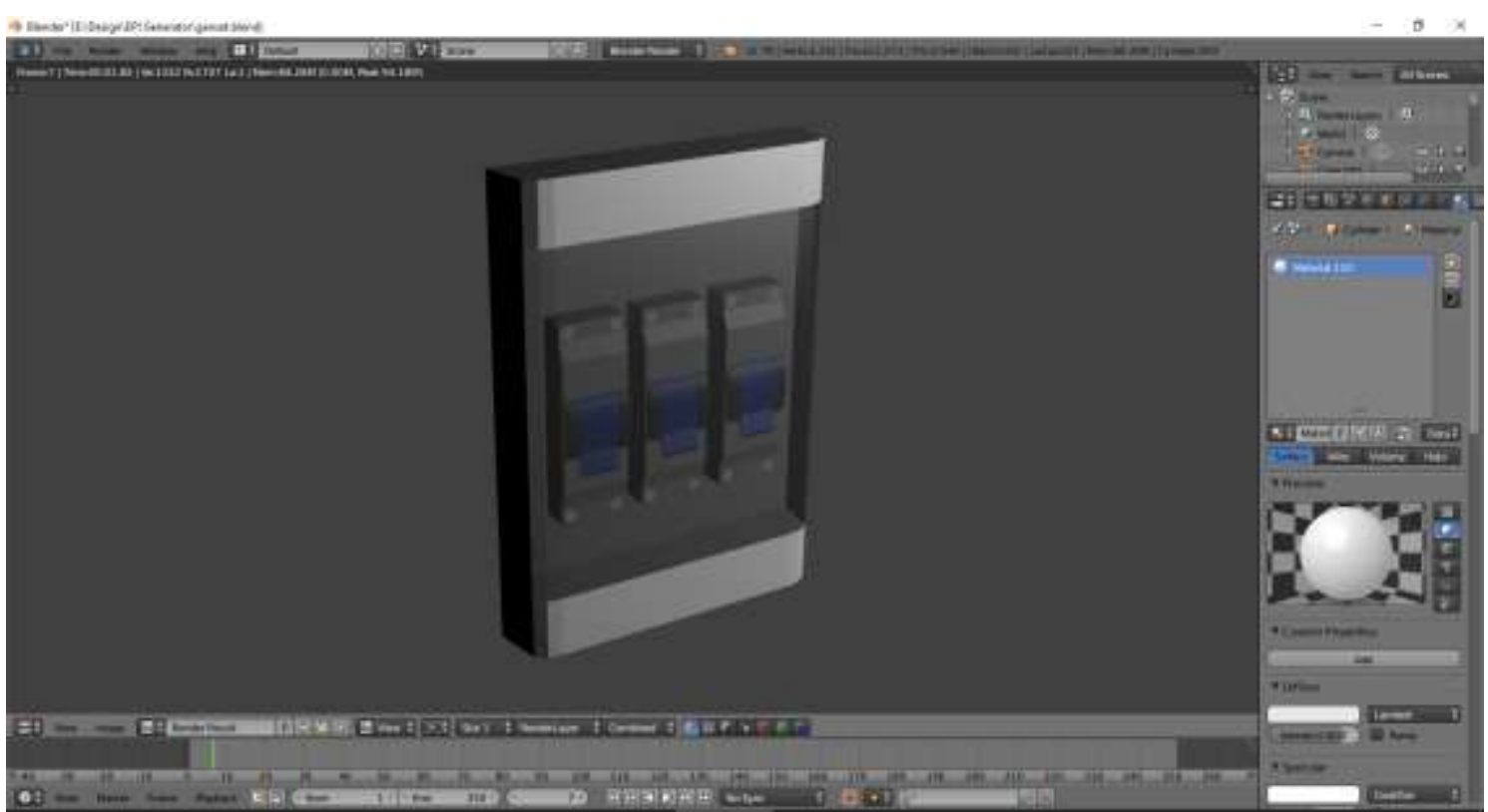

Gambar 9. Hasil rendering panel watt indicator switch

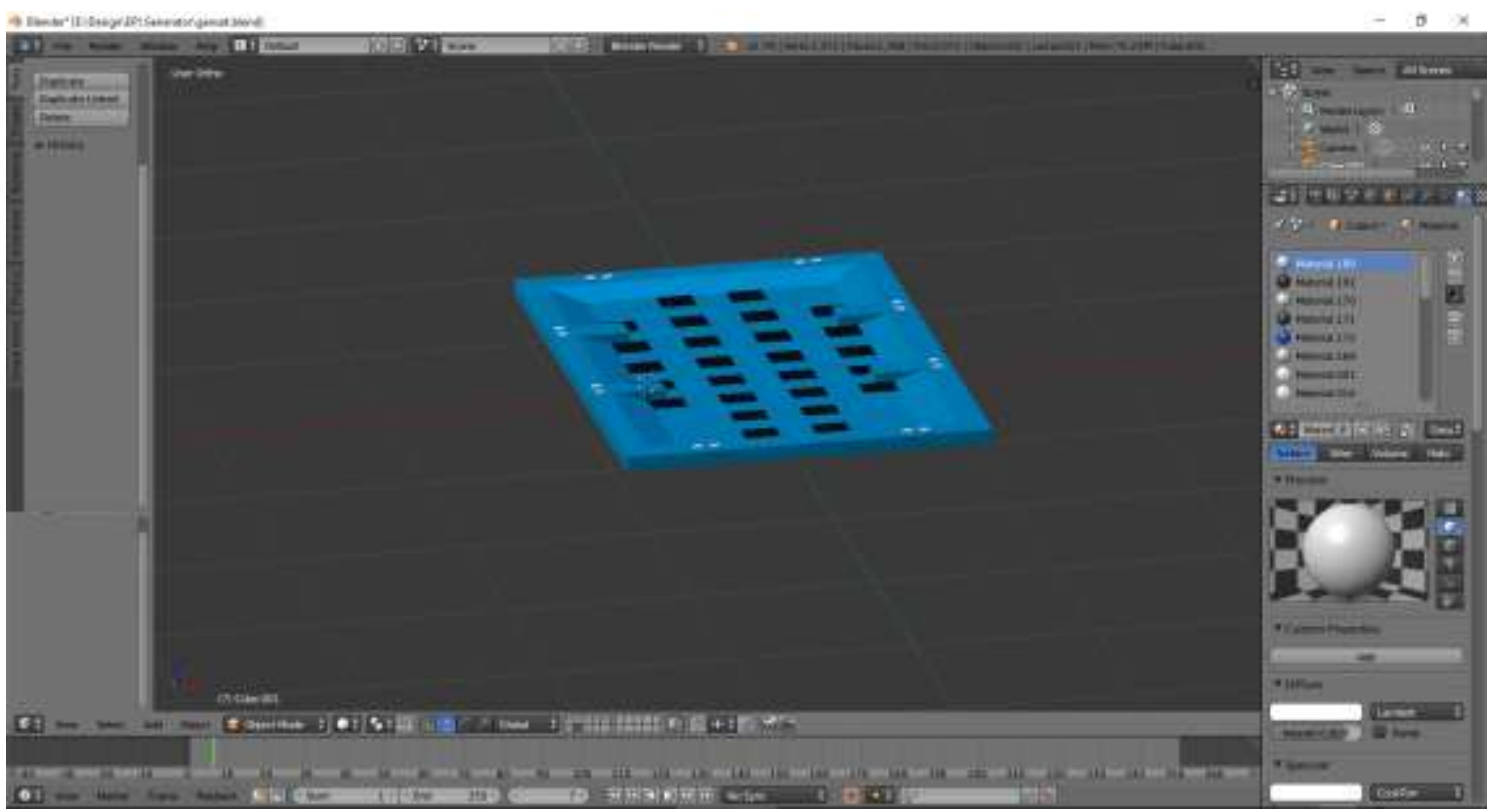

Gambar 10. Perancangan model ventilating panel dengan teknik subdivide vertice objek dan menghilangkan face serta memberikan warna material 


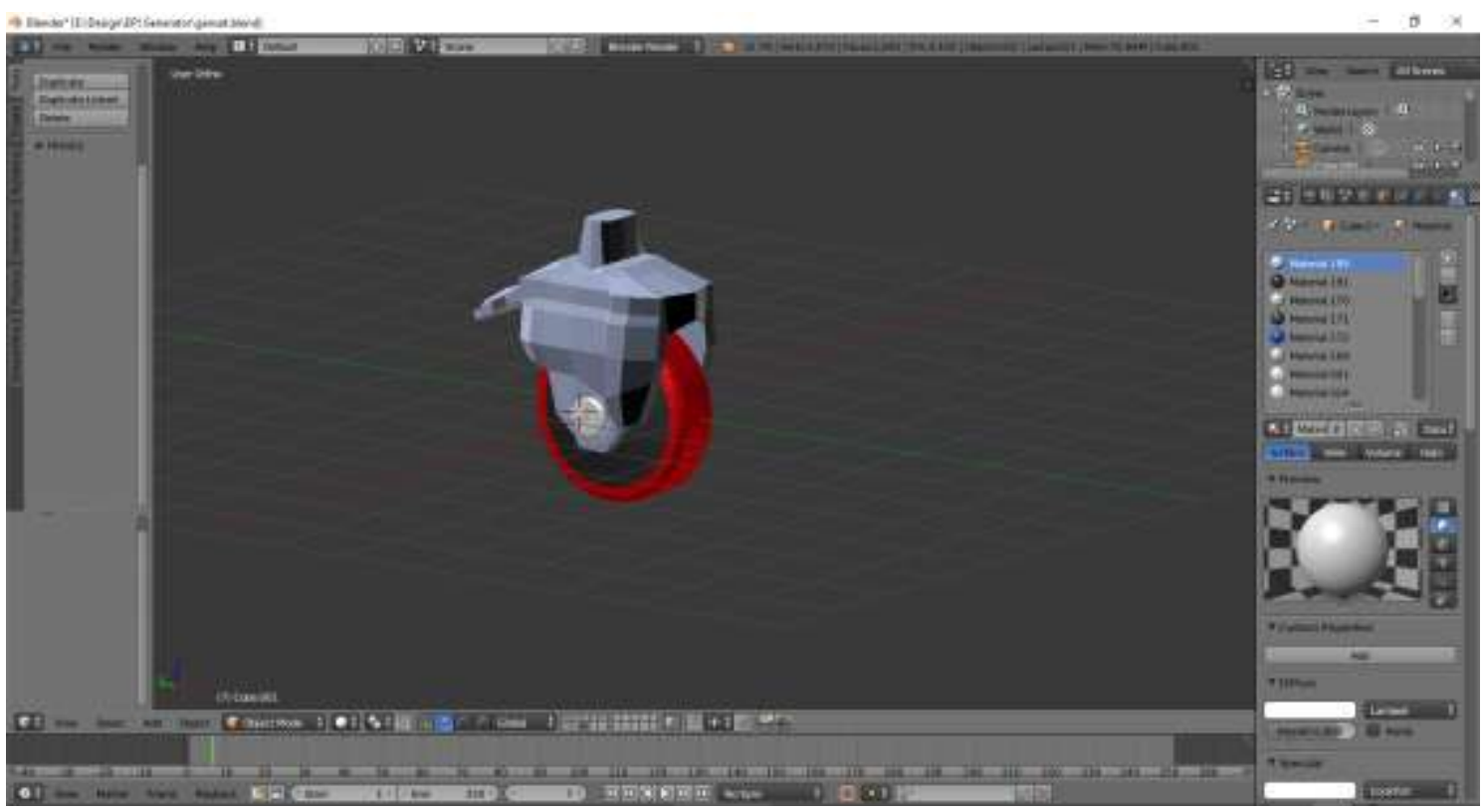

Gambar 11. Perancangan model roda penyangga mesin dengan teknik subdivide vertice objek dan menghilangkan face serta memberikan warna material

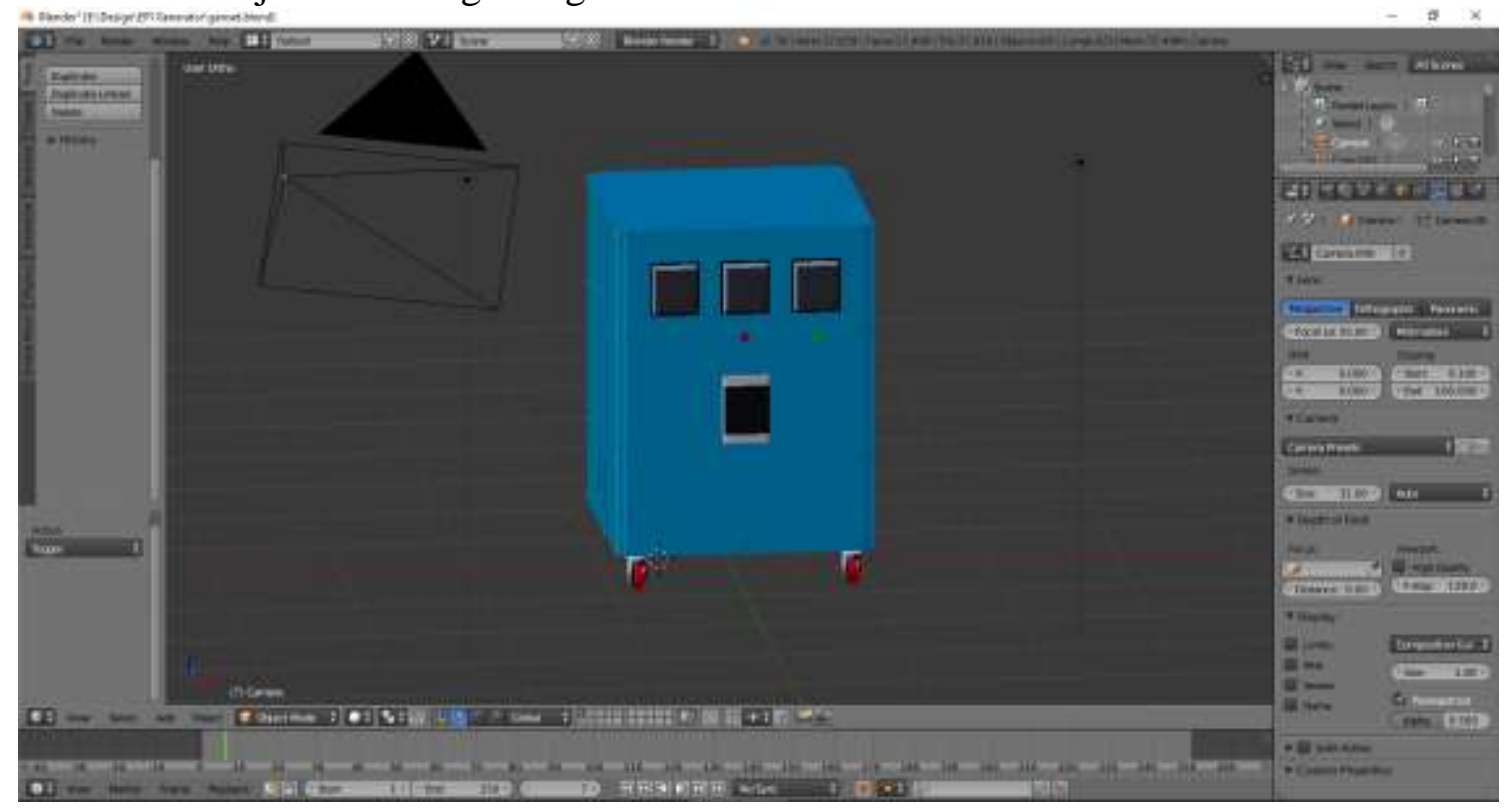

Gambar 12. Penggabungan objek-objek sehingga terlihat menjadi sebuah bentuk mesin EPI 


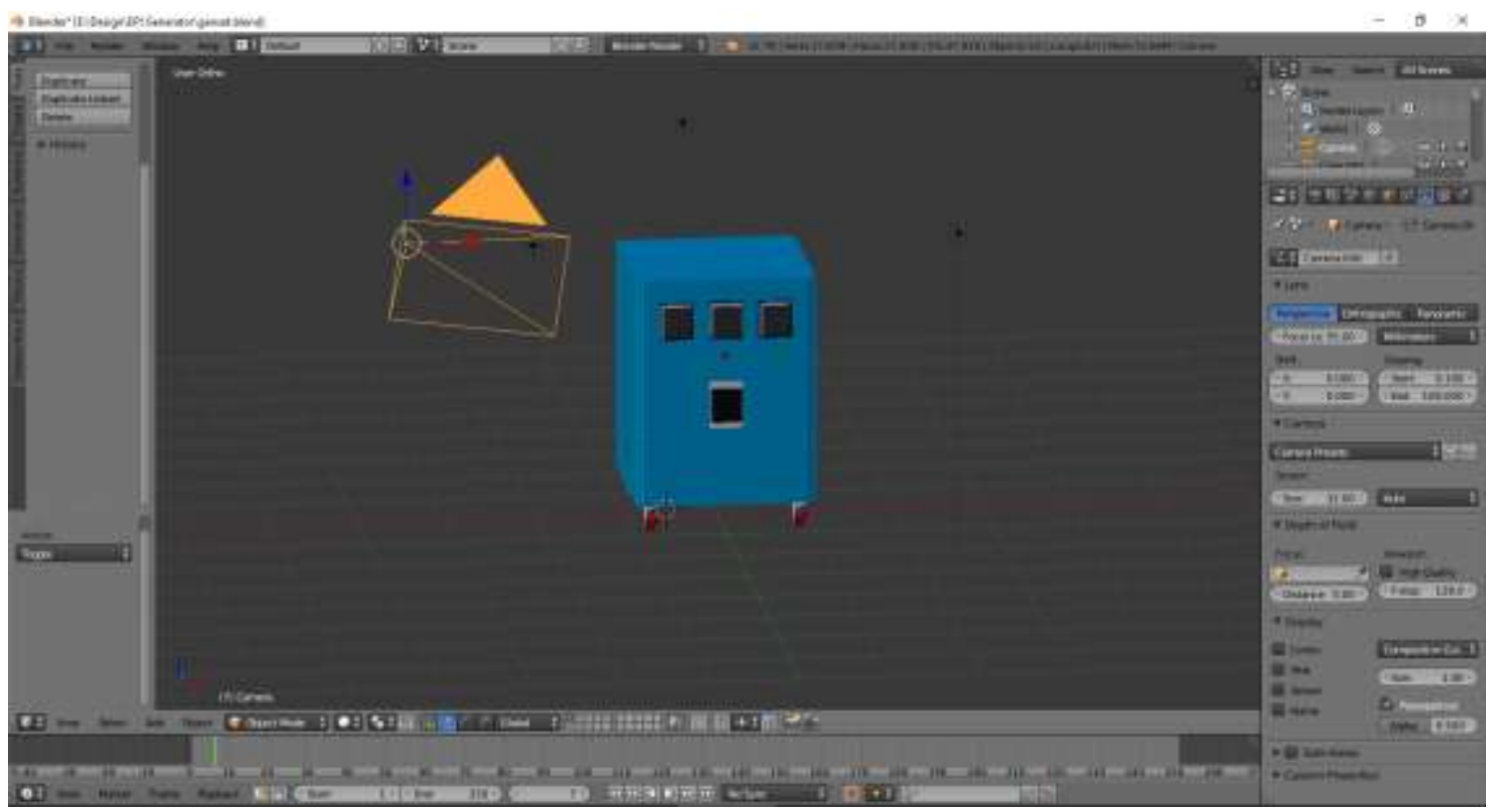

Gambar 13. Pemasangan objek camera sebagai titik perspektif hasil rendering akhir

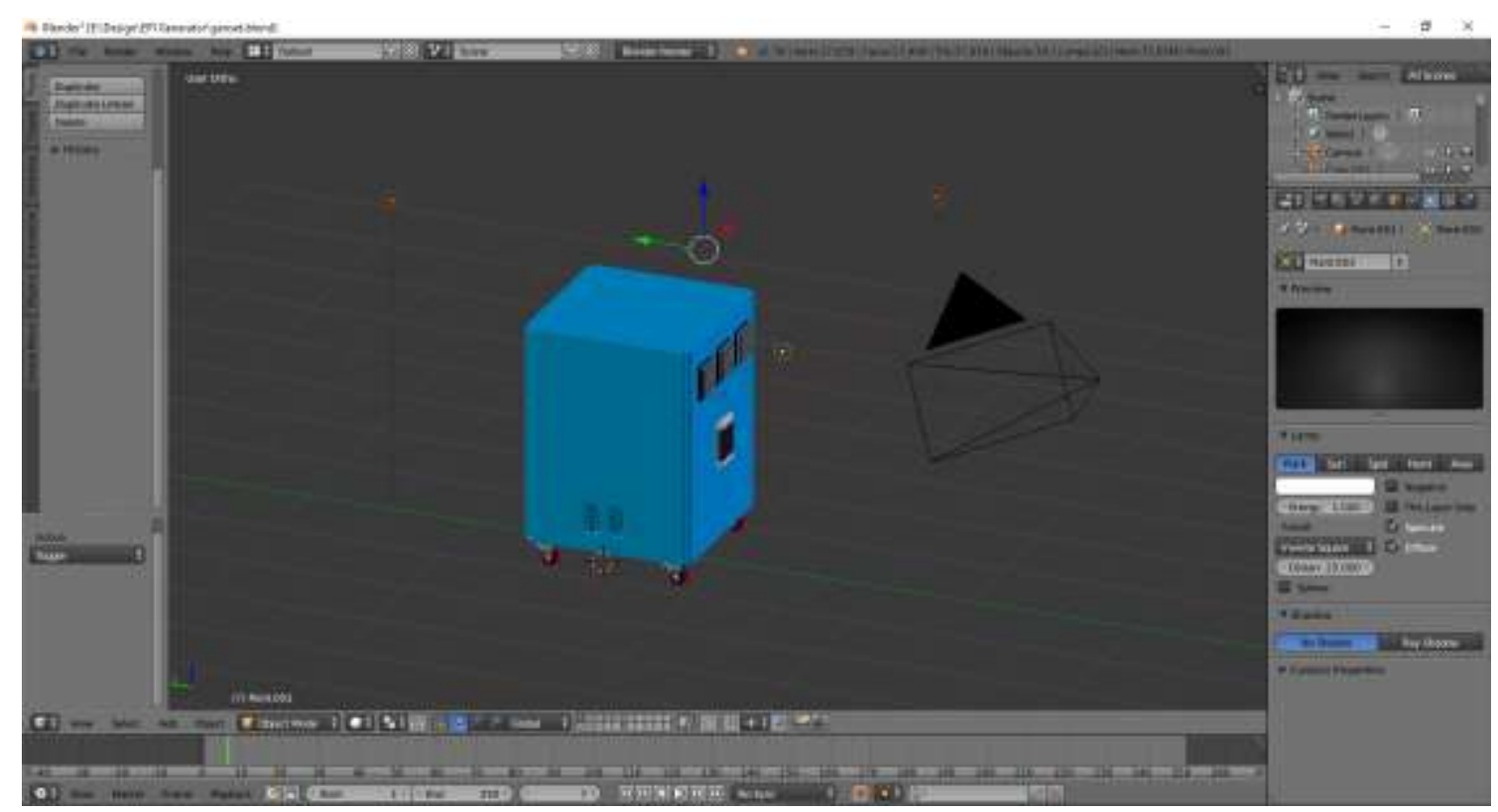

Gambar 14. Pemberian 3 objek lampu untuk pencahayaan pada saat hasil rendering akhir 


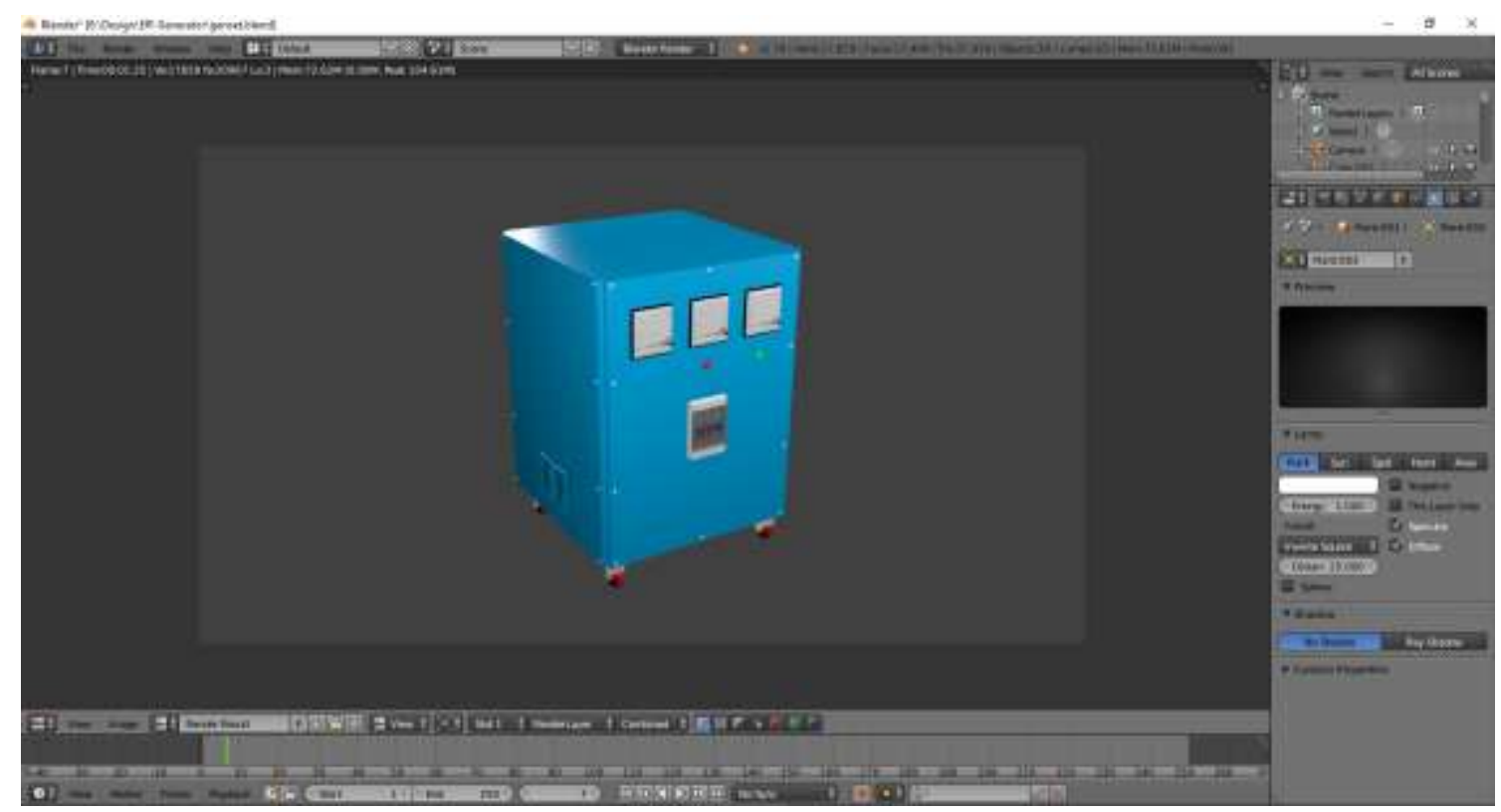

Gambar 15. Hasil rendering akhir mesin EPI secara 3 dimensi

\section{Kesimpulan}

Desain 3 dimensi sebenarnya bukanlah hal baru di dunia desain, tetapi jika diaplikasikan pada bidang yang tepat akan meningkatkan efisiensi proses dan lebih meningkatkan pula presisi dalam produksi sebuah produk dari perusahaan,

Pengalihan desain dari model konvensional (dengan memakai desain secara 2 dimensi dengan media kertas sebagai hasil akhir) menjadi 3 dimensi dapat memudahkan setiap perusahaan pemakai jasa desain secara 3 dimensi dalam melihat produk yang akan dikembangkan maupun diproduksi dari berbagai perspektif, sehingga dapat memperkecil resiko kesalahan dalam produksi. Selain itu pula perusahaan dapat meminta desainer untuk meng-animasikan atau menggerakan objek yang telah dibuat agar perusahaan dengan mudah mempresentasikan desain tersebut jika dikemudian hari produk tersebut akan dijual atau dipromosikan.

\section{Daftar Pustaka}

[1] Agus Suheri., 2006, Animasi Multimedia Pembelajaran, Jakarta : Elec Media Komputindo.

[2] Fernandez, Ibiz., 2002, Macromedia Flash Animation \& Cartooning: A creative Guide. McGraw- Hill/Osborn, California

[3] Hendratman, H., 2015, The Magic Of Blender 3D Modelling 37 Total Tutorials + DVD. Informatika

[4] M. Suyanto, 2005, Multimedia Alat untuk Meningkatkan Keunggulan Bersaing, Yogyakarta : Penerbit Andi

[5] Supriyono, Rakhmat, 2010, Desain Komunikasi Visual, Jakarta : Penerbit Andi

[6] Van Gumster, Jason., 2011, Blender For Dummies; 2 edition. For Dummies 